\section{Re: Antibiotikabruk i sykehus og sykehjem}

I Tidsskriftet nr. 5/2017 omtales økende antibiotikaresistens (1) og bruk av bredspektret antibiotika ved urinveisinfeksjoner på sykehjem (2) med budskap om å følge de nasjonale retningslinjene for antibiotika bruk i primærhelsetjenesten (3). Vi har nylig publisert en evaluering av urindyrkningssvar og empirisk behandling hos 161 ikke-gravide kvinner med mistenkt akutt cystitt i en solopraksis (4). Vi fant signifikant oppvekst hos $62 \%$ av 126 pasienter som startet antibiotikabehandling. E.coli stod for $75 \%$ av infeksjonene, og for alle påviste bakterier var hyppigheten av resistens mot nitrofurantoin $7 \%$, pivmecillinam $20 \%$, trimethoprim $20 \%$ og amoxicillin $33 \%$. For de to mest brukte antibiotika - pivmecillinam og trimethoprim - må man altså kunne påregne terapisvikt hos opptil $20 \%$ av pasientene. 15 pasienter $(9 \%)$ hadde glede av dyrkningssvaret ved at de enten skiftet $(n=10)$ eller startet $(n=5)$ antibiotikabehandling.

Tilsvarende fant vi positiv nasofarynksdyrkningssvar hos knapt halvparten av pasientene med akutt sinusitt $(n=220)$ (upubliserte datea). Etter retningslinjene skal penicillin være førstevalg og behandling først gis etter symptomvarighet på minst en uke (3). I vår studie var bare $43 \%$ av bakteriene følsomme for penicillin, hovedsakelig pga. oppvekst av Haemophilus influenzae (42\%) og Moraxella catarrhalis (10\%). Det bemerkes også at det ikke var noen signifikant forskjell i varighet av symptomer mellom de med og uten oppvekst. $14 \%$ av pasientene enten skiftet $(n=18)$ eller startet antibiotikabehandling $(\mathrm{n}=13)$ ut fra oppvekstsvar og manglende klinisk bedring. Vi antar at mange allmennpraktikere har tilsvarende erfaring med terapisvikt med penicillin ved bihulebetennelse, og at noen pasienter ikke lar seg motivere til å avvente behandling den første uken med symptomer.

Vi støtter opp under de norske retningslinjene for antibiotikabehandling ved cystitt og sinusitt, men vårt budskap er for det første at mange cystitter og sinusitter kan gå spontant over uten antibiotikabehandling. For det andre kan på fastlegekontorer dyrkningsprøver motivere pasienter til å avvente behandling og sikre målrettet antibiotikabehandling ved manglende spontanbedring. Man må dessverre akseptere at en del vil trenge bredspektret antibiotika. Denne fremgangsmåten vil føre til økt mikrobiologisk prøvetakning, men kan bidra til redusert bruk av antibiotika og mer målrettet behandling. For det tredje kan i legevaktsammenheng en vent-ogse-resept være en løsning, men norske erfaringer viser at knapt halvparten av pasientene henter ut en slik resept (5).

\section{Stephanie Knudtzon \\ stephanie.knudtzon@gmail.com \\ Jørgen Knudtzon}

Stephanie Knudtzon (f. 1992) er medisinstudent ved Norges teknisknaturvitenskapelige universitet i Trondheim.

Ingen oppgitte interessekonflikter.

Jørgen Knudtzon (f. 1954) er spesialist i barnesykdommer og allmennmedisin, og fastlege ved Sinsen legesenter.

Ingen oppgitte interessekonflikter.

\section{Litteratur}

1. Simonsen GS. Antibiotikabruk i sykehus og sykehjem. Tidsskr Nor Legeforen 2017; 137: 340

2. Alberg T, Holen $\emptyset$. Blix HS et al. Antibiotikabruk og infeksjoner i sykehjem. Tidsskr Nor Legeforen 2017; 137: 357-61.

3. Antibiotikabruk i primærhelsetjenesten. www.antibiotikaiallmennpraksis.no/ (11.3.2017).

4. Knudtzon S, Knudtzon J. Usefulness of urine culture from healthy non-pregnant women with uncomplicated cystitis. Infect Dis (Lond) 2017; Mar 3: 1-3.

5. Høye S, Frich J, Lindbœk M. Delayed prescribing for upper respiratory tract infections: a qualitative study of GPs' views and experiences. Br J Gen Pract 2010; 60: $907-12$.

\section{Re: Etikk og estetikk ved prehospital torakotomi}

Vi setter pris på det store engasjementet som vårt innlegg om prehospital torakotomi i Tidsskriftet nr. 23-24/2016 har skapt (1). Søreide og medarbeidere er i sitt innlegg (2) kritiske til ressursbruken knyttet til etableringen av denne prosedyren i Norge og argumenterer for at inngrepet kan være skadelig. Det er meget viktig å understreke at prehospital torakotomi kun skal vurderes utført på selekterte pasienter med traumatisk hjertestans grunnet penetrerende skade som man ellers ville erklært døde på skadestedet (3-5). Med dette som bakgrunn er det derfor vanskelig å se at inngrepet kan være skadelig. Videre mener vi mener at lav forekomst av en tilstand ikke alene utgjør et gyldig argument for ikke å anvende en potensielt livreddende prosedyre. Eksempelvis unnlater vi ikke å etablere kirurgisk luftvei i en kritisk situasjon på en pasient med det argument at prosedyren utføres sjeldent. Sammenlikningen mellom prehospital torakotomi og kirurgisk luftvei er relevant. Det er ytterst sjeldent behov for å utføre disse prosedyrene, og kunnskapen om dem baserer seg på kasusserier $(6,7)$.

Det henvises til argumentet om uforsvarlig ressursbruk. Trening på torakotomi foregår imidlertid i allerede etablerte kurs der blødningskontroll, avlasting av overtrykkspneumothoraks og vanskelig luftvei har hovedfokus. Den resucitative torakotomiprosedyren innøves i forlengelsen av trening på avlasting av overtrykkspneumothoraks, og legger i liten grad beslag på ytterligere ressurser. Det er derfor ikke korrekt når det hevdes at trening på prehospital torakotomi er uansvarlig bruk av helseressurser.

Søreide og medarbeidere refererer til en artikkel som viser at uavlastet overtrykkspneumothorax er en av hovedårsakene til dødsfall ved traumatisk hjertestans og at prehospital torakotomi ikke er indisert for å avlaste denne (8). Vi beklager at det i beskrivelsen av prosedyren i vår artikkel ved en inkurie ble oppgitt at det initialt utføres bilateral torakotomi - det korrekte er at det utføres bilateral torakostomi. Hvis pasienten på dette tidspunktet gjenvinner sirkulasjon på grunn av avlastet overtrykkspneumothorax, avbrytes prosedyren. Søreide og medarbeidere opplyser videre at tre av fire behandlingsfeil ved traumatisk hjertestans forekommer prehospitalt (8). Vi har utelukkende drøftet prehospital thorakotomi ved penetrerende skademekanisme, men i den artikkelen det refereres til, omtaler man imidlertid en studie av traumatisk hjertestans hos barn ved stump skademekanisme, og dette er ikke sammenlignbare pasientgrupper (9). Videre skriver de avslutningsvis: «Eksperimentelle metoder bør uansett ikke innføres uten at de implementeres i en etisk godkjent studie». Hva som kan betraktes som «eksperimentelt» er ikke entydig, og mange tiltak i akuttmedisinen baserer seg på sparsomt kunnskapsgrunnlag. Enten vi befinner oss ved operasjonsbordet, på intensivavdelingen eller på fortauet, må vi fortsatt kunne bruke anatomisk og fysiologisk forståelse i møte med våre aller sykeste pasienter.

\section{William Ottestad \\ Per B. Bredmose \\ Per Olav Berve \\ Halvard Stave \\ Gunnar Farstad \\ Lars Wik \\ Mårten Sandberg}

marten.sandberg@gmail.com

William Ottestad (f. 1974) er spesialist i anestesiologi og overlege ved Luftambulanseavdelingen, Oslo universitetssykehus.

Ingen oppgitte interessekonflikter.

Per B. Bredmose (f. 1973) er spesialist i anestesiologi og jobber som overlege med prehospital medisin og transportmedisin ved Luftambulanseavdelingen, Oslo universitetssykehus. Forfatteren har tidligere jobbet ved London's Air Ambulance fra The Royal London Hospital i London og har erfaring med prehospital torakotomi og medisinsk pedagogikk og undervisning i denne prosedyren.

Ingen oppgitte interessekonflikter. 
Per Olav Berve (f. 1976) er spesialist anestesi og overlege ved Anestesiavdelingen Oslo universitetssykehus, Ullevål, Luftambulanseavdelingen, Oslo universitetssykehus Legeambulansen $119 \mathrm{og}$ ph.d.-stipendiat ved Nasjonal kompetansetjeneste for prehospital akuttmedisin (NAKOS). Ingen oppgitte interessekonflikter.

Halvard Stave (f. 1976) er spesialist i anestesiologi og seksjonsoverlege ved Luftambulanseavdelingen, Oslo universitetssykehus.

Ingen oppgitte interessekonflikter.

Gunnar Farstad (f. 1967) er spesialist i anestesiologi og overlege ved Luftambulanseavdelingen, Oslo universitetssykehus.

Ingen oppgitte interessekonflikter.

Lars Wik (f. 1957) er spesialist i anestesiologi, overlege ved Anestesiavdelingen, Oslo universitetssykehus, Ullevål, Luftambulanseavdelingen, Oslo universitetssykehus, Legeambulansen 119 og seniorforsker ved Nasjonal kompetansetjeneste for prehospital akuttmedisin (NAKOS)

Oppgitte interessekonflikter: Forfatter er «principal investigator» for en hjertestansstudie støttet av Physio-Control, og han har patenter lisensiert fra Inven2 til Zoll Medical og Physio-Control.

Mårten Sandberg (f. 1960) er spesialist i anestesiologi og overlege ved Luftambulanseavdelingen, Oslo universitetssykehus, og professor II i prehospital akuttmedisin, Universitetet i Oslo.

Ingen oppgitte interessekonflikter.

\section{Litteratur}

1. Ottestad W, Bredmose PB, Berve PO et al. Prehospital torakotomi ved traumatisk hjertestans. Tidsskr Nor Legeforen 2016; 136: 1964-5

2. Søreide K, Vetrhus M, Weber C. Etikk og estetikk ved prehospital torakotomi. Tidsskr Nor Legeforen 2017; 137: 266-7.

3. Davies GE, Lockey DJ. Thirteen survivors of prehospital thoracotomy for penetrating trauma: a prehospital physician-performed resuscitation procedure that can yield good results. J Trauma 2011; 70: E75-8.

4. Kaljusto ML, Skaga NO, Pillgram-Larsen J et al. Survival predictor for penetrating cardiac injury; a 10-year consecutive cohort from a scandinavian trauma center. Scand J Trauma Resusc Emerg Med 2015; 23: 41.

5. Coats TJ, Keogh S, Clark H et al. Prehospital resuscitative thoracotomy for cardiac arrest after penetrating trauma: rationale and case series. J Trauma 2001; 50: $670-3$

6. Lockey D, Crewdson K, Weaver A et al. Observational study of the success rates of intubation and failed intubation airway rescue techniques in 7256 attempted intubations of trauma patients by pre-hospital physicians. Br J Anaesth 2014: 113: $220-5$.
7. Lockey D, Crewdson K, Davies G. Traumatic cardiac arrest: who are the survivors? Ann Emerg Med 2006; 48: 240-4.

8. Kleber C, Giesecke MT, Lindner T et al. Requirement for a structured algorithm in cardiac arrest following major trauma: epidemiology, management errors, and preventability of traumatic deaths in Berlin. Resuscitation 2014; 85: 405-10.

9. Duron V, Burke RV, Bliss D et al. Survival of pediatric blunt trauma patients presenting with no signs of life in the field. J Trauma Acute Care Surg 2014; 77: $422-6$.

\section{Re: Farlige dobbeltforskrivninger}

En del av oss har i flere år forsøkt å gjennomføre virkestofforskrivning så konsekvent som mulig. I Tidsskriftets papirutgave nr. 5/ 2017 (1) har Statens legemiddelverk en helside: «Nytt om legemidler - Bør virkestofforskrivning bli obligatorisk?» Der står det mange fine ord om hvordan leger skal forholde seg og hvordan elektroniske pasientjournalsystemer bør legges til rette for dette, men faktum er at selve e-reseptmodulen (reseptformidleren) bare i begrenset grad gjør virkestofforskrivning mulig. Mange legemidler er mulig å forskrive generisk, men svært ofte nytter det ikke å forskrive virkestoffet, enten ikke i det hele tatt, eller kun med navn etterfulgt av «Bluefish», «Mylan» eller andre. I en del tilfeller er det mulig å forskrive generisk, men ikke velge den styrken eller pakningsstørrelsen man ønsker. Slik jeg ser det er alvorlige mangler ved e-reseptmodulen (reseptmidleren) som i dag vanskeliggjør den opprydning som etterlyses! Det må i e-reseptmodulen bli mulig å forskrive generisk alle godkjente stoffer $\mathrm{i}$ alle registrerte styrker og pakningsstørrelser.

\section{Arne Aarflot}

arne.aarflot@legekontoret.com

Arne Aarflot er spesialist i allmennmedisin og fastlege ved Legekontoret på Tolvsrød.

Ingen oppgitte interessekonflikter.

\section{Litteratur}

1. Lyftingsmo S. Farlige dobbeltforskrivninger. Tidsskr Nor Legeforen 2017; 137: 348. 